\title{
A Study on Training Needs Assessment of Rice Growing Farmers in Imphal East District, Manipur, India
}

\author{
Niranda Sharma Leihaothabam ${ }^{1}$, Aheibam Tarajit Singh ${ }^{2}$, \\ Khumukcham Stina ${ }^{3}$, Mutum Suraj Singh ${ }^{3}$, Rajkumar Sandeep Singh ${ }^{3}$, \\ Yaikhom Vivekananda ${ }^{3}$ and Konsam Cha Shyamananda ${ }^{3}$
}

\author{
${ }^{1}$ Pandit Deen Dayal Upadhyay Institute of Agricultural Sciences, \\ Utlou, Bishnupur, Manipur, India \\ ${ }^{2}$ KVK Utlou, Bishnupur, Manipur \\ ${ }^{3}$ Central Agricultural University, Imphal, Manipur \\ *Corresponding author
}

\section{A B S T R A C T}

\section{Keywords}

Socio-personal, Psychological and communication characteristics, Training needs assessment, Dependent and independent variables, Constraints

Article Info

Accepted:

05 February 2020 Available Online: 10 March 2020
Rice (Oryza sativa L.) is one of the most important staple food crops of India for more than $2 / 3$ rd of its population. Considering the importance regarding the training needs assessment of the respondents, the present study was conducted in Keirao Bitra subdivision of Imphal East District, Manipur. Ten independent variables were selected regarding the socio-personal, psychological and communication characteristics of the respondents. Out of 38 villages in Keirao Bitra sub-division, 4 villages viz., Angtha, Top Chingtha, Nungbrung \& Yambem were selected through random sampling method and a total of 120 respondents were selected for the study. The selected respondents were interviewed personally using pre-tested well-structured questionnaire schedule. Correlation analysis between training needs areas of the respondents and the independent variables revealed that out of ten independent variables, three independent variables i.e, cropping intensity, attitude towards pesticide used and economic motivation were found to be positively significant at 0.01 level of probability whereas age, education, extension contact and mass media exposure had negative correlation significant at 0.01 level of probability. Further the respondents were classified into three categories as low, medium and high training needs, based on the score of their training need areas of rice cultivation. Majority of the farmers had medium level $(58.33 \%)$ of training needs followed by low level $(23.34 \%)$ and high level $(18.33 \%)$ of training needs. The major areas in which farmers were considered to be high priority areas in respect of training requirement were water management, weed management, sowing and transplanting, nutrient management and seed selection and treatment. Therefore, it may be concluded that there was a need to impart scientific knowledge to the farmers by way of training to enhance their knowledge regarding improved paddy production technology to increase the rice production. 


\section{Introduction}

Rice (Oryza sativa L.) is one of the most important staple food crops of India for more than $2 / 3 \mathrm{rd}$ of its population. The slogan "Rice is life" can be considered appropriate for our country as this crop plays a vital role in our national food security and is a means of livelihood for millions of rural households. About 90 per cent of people are rice eaters in seven countries of Asia namely India, Bangladesh, Cambodia, Laos, Myanmar, Sri Lanka and Vietnam. Asia's food security depends largely on the irrigated rice fields which accounts for more than 75 per cent of the total rice production (Virk et al., 2004). To assure food security in the rice consuming countries of the world, rice production would have to be increased by 50 per cent in these countries by 2025 and, this additional yield will have to be produced on less land with less usage of water, labour and chemicals (Zeng et al., 2004).In Manipur, the area under paddy cultivation is 2.36 lakh hectares with a production of 607.82 metric tonnes and productivity of $2.57 \mathrm{Mt} / \mathrm{ha}$ according to the 2017-18 report (Source: Department of Agriculture, Govt. of Manipur). Although the yield still exists lower than all the Indian level of 104.80 million tonnes meaning there is a wide gap to be recovered by increasing the yield potential at farmer's field by adopting scientists recommended production technologies. Hence, in order to meet the ever increasing demand, the present level of rice production needs to be enhanced.

\section{Materials and Methods}

\section{Research methodology}

\section{Research and sampling design}

Ex-post facto research design was adopted and stage sampling procedure was adopted to select the appropriate number of the respondents. The study was conducted at
Imphal East District. The district is divided into 3 sub- divisions: Keirao Bitra, Porompat and Sawombung. Since it was not possible to conduct an intensive study of the entire district due to limited time, only one sub-division i.e., Keirao Bitra was selected purposively because majority of the farmers were rice cultivators. Out of the total 38 villages in Keirao Bitra sub-division, four villages viz., Angtha, Nungbrang, Top Chingtha and Yambem were selected for the study. An equal number of respondents (30 each) were selected from each village and make up a total of 120 respondents.

\section{Methods of data collection}

Data were collected both from the primary and secondary sources. For the purpose of the present work, qualitative and quantitative data were collected. From primary source structured interview schedule data collection was employed. Data were collected from the single respondent through single interview method.

\section{Statistical tools used for analysis of data}

The data collected through the schedule were coded, tabulated analyzed and presented in tables in order to make the findings meaningful and easily understandable. The findings emerging from the analysis of the data were suitably interpreted and inferences were drawn. The statistical tools and techniques used in the study are given below:

\section{Arithmetic mean}

Arithmetic mean is the quotient that results when the sum of all the items in the series is divided by the numbers of items (n). It is denoted by

$\bar{X}=\frac{\sum \mathrm{X}_{\mathrm{i}}}{\mathrm{N}}$ 
Where,

$\sum^{X_{i}}=$ summation of item values

$\mathrm{N}=$ no. of items

$\bar{X}=$ arithmetic mean

\section{Standard deviation}

Standard deviation is the square root of the arithmetic mean of the squares of all the deviation, the deviations being measured from the arithmetic mean of the squares of all the deviation, the deviations being measured from the arithmetic mean of the distribution. It is commonly denoted by the symbol ${ }^{\sigma}$ (sigma). It is less affected by the sampling errors and is more stable measure of dispersion.

The standard deviation of the data group in the form of a frequency distribution is computed by the formula

$\sigma=\sqrt{\frac{\sum f d^{2}}{N}}$

Where,

$\mathrm{f}=$ frequency of the class

$\mathrm{d}=$ deviation of the mid-value of the class from the population mean

$\mathrm{N}=$ total number of observation

\section{Frequency and percentage}

Percentage was used for making simple comparisons. For calculating percentage, the frequency of a particular cell was divided by the number of respondents in that category and multiplied by 100

\section{Correlation}

When an increase or decrease in one variate is accompanied by an increase or decrease in other variate, the two are said to be correlated and the phenomenon is known as correlation coefficient (r) a measure of the relationship between two variables which arc at the interval or ratio level of the measurement and are linearly related. A Pearson productmoment ' $r$ ' is computed by the formula

$\mathrm{r}=\frac{N 2 X Y-(2 X)(2 Y)}{\sqrt{\left[N \sum X^{2}-\left(\sum X\right)^{2}\right\}\left[N \sum Y^{2}-\left(\sum Y\right)^{2}\right]}}$

Where,

$\mathrm{X}$ and $\mathrm{Y}=$ original scores in variables $\mathrm{X}$ and $\mathrm{Y}$ $\mathrm{N}=$ number of paired scores

$\sum X Y=$ each of $\mathrm{X}$ multiplied by its corresponding $\mathrm{Y}$, then summed

$\sum^{X^{2}}=$ each $\mathrm{X}$ squared, then sum

$\sum X=$ sum of $X$ scores

$\left(\sum^{X}\right)^{2}=$ sum of $X$ scores, squared

$\sum \mathrm{Y}=$ sum of $\mathrm{Y}$ scores

$\sum^{Y^{2}}=$ each $Y$ squared, then summed

$\left(\sum^{Y}\right)^{2}=$ sum of Y scores, squared

\section{Results and Discussion}

Findings of the present investigation on training needs assessment of the respondents are present under the following heads.

\section{Socio-personal, physiological and communication characteristics of the respondents}

It was revealed from table 1 that the parameters of age for the farmers of the middle age group were found as majority $(69.17 \%)$ followed by young age group $(20.00 \%)$ and old age group $(10.83 \%)$. The possible reason would be that middle age farmers were physically fit to withstand the stress and risks involved in rice production, and were more mentally alert to embrace new techniques of rice production. For education, $41.66 \%$ of the respondents are maximum in the category of primary school, followed by high school (19.16\%), read and write 
(17.50\%), middle school (14.16\%), higher secondary $(6.67 \%)$, read only $(0.84 \%)$ and lastly, no illiterate respondents was found $(0.00 \%)$. This is because with the change in their society from traditional to modern one, education is more formal and systematically organized. For cropping intensity the largest percentage of the respondents $(60.00 \%)$ belonged to the group 100-150 followed by group 151-200 (24.16\%). Only (15.84\%) respondents belonged to cropping intensity group 201 and above. The respondents (41.67\%) who owned a small size of land (less than 1 ha) has largest percentage, followed by $(35.83 \%)$ belonged to medium (1-2 ha) and $(22.50 \%)$ owned a land size more than 2 ha. The reason might be that the families separated after marriage and so as the land holding is fragmented. On the basis of their attitude of farmers towards pesticides use scores indicated that of the total sample, majority of farmers $(80.00 \%)$ were in the medium category farmers followed by high category farmers $(13.33 \%)$ and low category farmers $(6.67 \%)$. It may, therefore, be inferred that the farmers were aware about the insect pests and diseases etc. which are negative factors of crop production and can substantially reduce the yield unless they are properly taken care of.

Majority of the respondents (95.83\%) belonged to medium income group followed by high income groups (3.34\%). Only $(0.83 \%)$ of the respondents belonged to low income group. It indicates that in addition to agriculture, they have other sources of income. Out of the 120 farmers, (75.83\%) belonged to small family and $(24.17 \%)$ belonged to large family. The reason could be that their family might be separated after marriage and followed by fragmentation of the land holding. It was also found that majority of the respondents $(63.33 \%)$ have medium economic motivation followed by low $(24.17 \%)$ and only $(12.50 \%)$ have high economic motivation. This indicates that farmers have a strong desire towards economic motivation. The highest score was associated with medium extension contact $(50.84 \%)$ followed by low (30.00\%) and high (19.16\%) extension contact category. The possible reasons attributed for high level of extension contact means there is no lack of field visits by extension personal. Majority of the farmers (77.50\%) had medium mass media exposure, followed by high $(21.67 \%)$ and low $(0.83 \%)$ mass media exposure. It may therefore, be inferred that majority of them had used mass-media to a greater extent as farm innovation sources.

\section{Training needs areas of the respondents in rice production}

The main focus of the research work is to ascertain the training need areas in different broad activities of rice cultivation. The term training is teaching, or developing in oneself or others, any skills and knowledge that relate to specific useful competencies. Table 1 reveals that majority $(58.33 \%)$ of the farmers had medium level of training need areas followed by low (23.34\%) and high (18.33\%) level of training need areas of the respondents. Similar finding was also reported by Chawang and Jha (2010).

\section{Relationship between the socio-personal, psychological and communication characteristics with their training need areas of the respondents}

This section deals with the nature of relationship between selected dependent variables and independent variables. For ascertaining the relationship correlation coefficient ( $r$ ) was calculated between dependent variable separately for the sample farmers. The ' $r$ ' values are given in Table 2.

It is evident from Table 2 that the correlation coefficient between age and training need 
areas of the respondents were found to be negatively significant at 0.01 level, with the corresponding ' $r$ ' value -0.898 .This indicates that higher the age of the respondents lower the training need areas in rice cultivation of the farmers. Similar finding was reported by Chawang and Jha (2010). There was a negative correlation between education and training need areas of the respondents at 0.01 significant levels with ' $r$ ' value -0.070 . This indicates that higher the level of education, lower the training need areas of the respondents. This finding agrees with the study done by Srivastava (2012). Cropping intensity and training need areas of the farmers shared a positive correlation at 0.01 significant level with ' $r$ ' value 0.797 . This indicates that, higher the cropping intensity, higher the training need areas of the respondents.

This finding agrees with the study done by Darnal and Bandiyopadhya (2014). Both the land holding and training need areas of the farmers shared a non-significant correlation with ' $r$ ' value 0.168 . This indicates that, there is no relation between land holding and training need areas of the respondents. Attitude towards pesticides used, training need areas of the farmers shared positive correlation at 0.01 significant level with ' $r$ ' value 0.287. The possible reason is that, higher the attitude towards pesticide used, higher the training need areas of the respondents. This finding agrees with the study done by Bekele et al., (2013). There was non-significant correlation between family income and training needs areas of the respondents with ' $r$ ' value -0.111 . Hence, family income of the family was not related to training need areas of the respondents. Both family size and training need areas of the respondents had nonsignificant correlation with ' $r$ ' value -0.105 . It can be included that family size was not related to training need areas of the respondents. In other words, all the farmers did not vary in their training need areas on the basis of family size. Similar finding was also reported by Chawang and Jha (2010).

For economic motivation and training need areas of the rice growers, it was found to be positively significant at 0.01 level with the corresponding ' $r$ ' value 0.799 . This indicates that higher the economic motivation of the respondent, higher the training need areas of the respondents. There was a negative correlation between extension contact and training need areas of the respondents at 0.01 significant level with ' $r$ ' value -0.612 . It can be concluded that, lower the extension contact leads to higher level of training need areas of the respondents. Related finding was reported by Verma et al., (2013). Mass media exposure and training need areas of the respondents shows negative correlation at 0.01 significant level with ' $r$ ' value of -0.545 . it can be concluded that, lower the exposure to mass media leads to higher level of training need areas of the respondents. Similar findings were reported by Anantharaman and Subramanyan (1982).

\section{Constraints faced by the respondents}

Based on the field of experience of research coupled with discussion with the respondents, experienced scientists of various field, field level extension functionaries and books and journals, constraints were enumerated and classified into bio-physical constraints, economic constraints and technological constraints. The respondents were asked to indicate the constraints experienced by them in adoption of modern rice technologies. Table 3 shows that inadequate irrigation facilities (77.50\%) was the most important constraint and weed problems was the least constraint faced by the respondents $(26.67 \%)$. The most important constraint faced by the respondents was high cost of input (80.83\%) and the least important constraint was lack of proper marketing facilities (17.50\%). 
Table.1 Distribution of respondents according to the dependent and independent variable scores

\begin{tabular}{|c|c|c|c|c|c|c|}
\hline SL.NO & $\begin{array}{l}\text { DEPENDENT } \\
\text { VARIABLE }\end{array}$ & CATEGORY & FREQUENCY & PERCENTAGE & MEAN & S.D \\
\hline 1. & Training needs area & $\begin{array}{l}\text { Low } \\
\text { Medium } \\
\text { High }\end{array}$ & $\begin{array}{l}28 \\
70 \\
22\end{array}$ & $\begin{array}{l}23.34 \\
58.33 \\
18.33\end{array}$ & 143 & 46 \\
\hline SL.NO & $\begin{array}{l}\text { INDEPENDENT } \\
\text { VARIABLES }\end{array}$ & CATEGORY & FREQUENCY & PERCENTAGE & MEAN & S.D \\
\hline 1. & Age & $\begin{array}{l}\text { Young (below } 37 \\
\text { years) } \\
\text { Middle (37-57 years) } \\
\text { Old (above } 57 \text { years) }\end{array}$ & $\begin{array}{l}24 \\
83 \\
13\end{array}$ & $\begin{array}{l}20 \\
69.17 \\
10.83\end{array}$ & 47 & 10 \\
\hline 2. & Education & $\begin{array}{l}\text { Illiterate } \\
\text { Can read only } \\
\text { Can read and write } \\
\text { Primary } \\
\text { Middle school } \\
\text { High school } \\
\text { Higher secondary }\end{array}$ & $\begin{array}{l}0 \\
1 \\
21 \\
50 \\
17 \\
23 \\
8\end{array}$ & $\begin{array}{l}0 \\
0.84 \\
17.50 \\
41.66 \\
14.16 \\
19.16 \\
6.67 \\
\end{array}$ & & \\
\hline 3. & Cropping intensity & $\begin{array}{l}100-150(\text { low }) \\
151-200(\text { medium }) \\
200 \& \text { above(large) }\end{array}$ & $\begin{array}{l}72 \\
29 \\
19\end{array}$ & $\begin{array}{l}60.00 \\
24.16 \\
15.84\end{array}$ & & \\
\hline 4. & Land holding & $\begin{array}{l}\text { Small (less than } 1 \text { ha) } \\
\text { Medium (1-2) } \\
\text { Large (more than } 2 \\
\text { ha) }\end{array}$ & $\begin{array}{l}50 \\
43 \\
27\end{array}$ & $\begin{array}{l}41.67 \\
35.83 \\
22.50\end{array}$ & 1.51 & 0.80 \\
\hline 5. & $\begin{array}{l}\text { Attitude of farmers } \\
\text { towards pesticide } \\
\text { used }\end{array}$ & $\begin{array}{l}\text { Low } \\
\text { Medium } \\
\text { High }\end{array}$ & $\begin{array}{l}8 \\
96 \\
16\end{array}$ & $\begin{array}{l}6.67 \\
80.00 \\
13.33\end{array}$ & 14.41 & 2 \\
\hline 6. & Family income & $\begin{array}{l}\text { Low (below ₹ } \\
49,000) \\
\text { Medium (₹ 49,000- } \\
115000 \text { ) } \\
\text { High(above ₹ } \\
115000)\end{array}$ & $\begin{array}{l}1 \\
115 \\
4\end{array}$ & $\begin{array}{l}0.83 \\
95.83 \\
3.34\end{array}$ & 82,000 & 33,000 \\
\hline 7. & Family size & $\begin{array}{l}\text { Small (less than equal } \\
\text { to 5) } \\
\text { Large(more than 5) }\end{array}$ & $\begin{array}{l}91 \\
29\end{array}$ & $\begin{array}{l}75.83 \\
24.17\end{array}$ & 5 & 1 \\
\hline 8. & $\begin{array}{l}\text { Economic } \\
\text { motivation }\end{array}$ & $\begin{array}{l}\text { Low } \\
\text { Medium } \\
\text { High }\end{array}$ & $\begin{array}{l}29 \\
76 \\
15\end{array}$ & $\begin{array}{l}24.17 \\
63.33 \\
12.50\end{array}$ & 15 & 3 \\
\hline 9. & Extension contact & $\begin{array}{l}\text { Low } \\
\text { Medium } \\
\text { High }\end{array}$ & $\begin{array}{l}36 \\
61 \\
23\end{array}$ & $\begin{array}{l}30.00 \\
50.84 \\
19.16 \\
\end{array}$ & 4.56 & 2 \\
\hline 10. & $\begin{array}{l}\text { Mass media } \\
\text { exposure }\end{array}$ & $\begin{array}{l}\text { Low } \\
\text { Medium } \\
\text { High }\end{array}$ & $\begin{array}{l}1 \\
93 \\
26\end{array}$ & $\begin{array}{l}0.83 \\
77.50 \\
21.67\end{array}$ & 12 & 4 \\
\hline
\end{tabular}


Table.2 Correlation of the socio-personal, psychological and communication characteristics with their training need areas of the respondents

\begin{tabular}{|c|c|c|}
\hline Sl. no. & Characteristics & Correlation coefficient (r) \\
\hline $\mathbf{1}$ & Age & $-0.898^{* *}$ \\
\hline $\mathbf{2}$ & Education & $-0.070^{* *}$ \\
\hline $\mathbf{3}$ & Cropping intensity & $0.797^{* *}$ \\
\hline $\mathbf{4}$ & Land holding & $0.168(\mathrm{NS})$ \\
\hline $\mathbf{5}$ & Attitude towards pesticide used & $0.287^{* *}$ \\
\hline $\mathbf{6}$ & Family income & $-0.111(\mathrm{NS})$ \\
\hline $\mathbf{7}$ & Family size & $-0.105(\mathrm{NS})$ \\
\hline $\mathbf{8}$ & Economic motivation & $0.799^{* *}$ \\
\hline $\mathbf{9}$ & Extension contact & $-0.612^{* *}$ \\
\hline $\mathbf{1 0}$ & Mass media exposure & $-0.545^{* *}$ \\
\hline
\end{tabular}

${ }^{* *}$ correlation is significant at the 0.01 level of probability

${ }^{*}$ correlation is significant at 0.05 level of probability

NS - Non Significant

Table. 3 Constraints scores

\begin{tabular}{|c|c|c|c|c|c|}
\hline SL.NO & CONSTRAINTS & CATEGORY & FREQUENCY & PERCENTAGE & RANK \\
\hline 1. & A. Bio-physical & $\begin{array}{l}\text { A) Unavailability of quality } \\
\text { seed } \\
\text { B) Weed problems } \\
\text { C) Inadequate irrigation } \\
\text { facilities } \\
\text { D) Incidence of insect pest }\end{array}$ & $\begin{array}{l}85 \\
32 \\
93 \\
65\end{array}$ & $\begin{array}{l}70.83 \\
26.67 \\
77.50 \\
54.16\end{array}$ & $\begin{array}{c}\text { II } \\
\text { IV } \\
\text { I } \\
\text { III }\end{array}$ \\
\hline 2. & B. Economic & $\begin{array}{l}\text { A) High cost of inputs } \\
\text { B) Lack of proper marketing } \\
\text { facilities } \\
\text { C) Non-availability of } \\
\text { insurance when crops fails } \\
\text { D) Lack of transport facilities } \\
\text { E) Poor/low yield of rice } \\
\text { crop }\end{array}$ & $\begin{array}{l}97 \\
21 \\
92 \\
\\
32 \\
27\end{array}$ & $\begin{array}{l}80.83 \\
17.50 \\
76.67 \\
\\
26.67 \\
22.50\end{array}$ & $\begin{array}{l}\text { I } \\
\text { V } \\
\text { II } \\
\text { III } \\
\text { IV }\end{array}$ \\
\hline 3. & C. Technological & $\begin{array}{l}\text { A) Lack of knowledge of } \\
\text { ipm/inm } \\
\text { B) Lack of suitable area } \\
\text { specific technology } \\
\text { C) No/less knowledge of } \\
\text { green manure (azolla) } \\
\text { uses/application }\end{array}$ & $\begin{array}{r}85 \\
93 \\
110\end{array}$ & $\begin{array}{l}70.83 \\
77.50 \\
91.67\end{array}$ & $\begin{array}{c}\text { III } \\
\text { II } \\
\text { I }\end{array}$ \\
\hline
\end{tabular}


No/less knowledge of green manure (Azolla) uses/application was the most important constraint faced by the respondents $(91.67 \%)$ and lack of knowledge of IPM/INM was the least important constraint faced among the respondents $(70.83 \%)$.

The present study can be concluded that majority of the respondent farmers of Keirao Bitra sub-division had medium level of training needs in relation to rice cultivation practices.

The major areas in which farmers were considered to be highest priority and least priority area were water management and pest management respectively. Independent variables age, education, extension contact and mass media exposure had negative and significantly correlated with the training needs of the respondents. Cropping intensity, attitude towards pesticide used and economic motivation had positive and significantly correlated with training needs of the respondents and land holding, family income and family size being non- significant with the training needs of the respondents. Thus, young farmers having less exposure is necessary training in relation to package of practices of the rice cultivation. Therefore, it may be concluded that there was a need to extent more scientific knowledge to the farmers by the way of training to improve their knowledge regarding improved rice production technology to increase the rice production.

Regarding the constraints faced by the rice grower, under bio-physical constraints, 77.50 per cent of the respondents faced inadequate irrigation facilities as major constraint and 26.67 per cent of the respondents having less constraint under weed problem. Considering, economic constraint high cost of inputs 80.83 per cent were faced by the respondents as majority and lack of proper marketing facilities 17.50 per cent having the least constraint. For technological constraints, the highest constraint faced by the respondents were no/less knowledge of green manure (Azolla) uses/application having 91.67 per cent and lack of knowledge of IPM/INM having 70.83per cent with least constraint faced by the respondents. Thus, most of the respondents faced inadequate irrigation facilities, cost of high inputs and less knowledge of green manure (Azolla) uses/application as their major constraint in rice cultivation.

\section{Acknowledgement}

The authors are thankful to the Pandit Deen Dayal Upadhyay Institute of Agricultural Sciences, Utlou, Bishnupur, Manipur for providing all the facilities provided during the course of study. Also gratitude and appreciation goes to Farmer FIRST Project team of CAU, Imphal for providing valuable suggestions and technical support during the whole period of study and analysis of data.

\section{References}

Anantharaman, M. and Subramanyan, V.S. (1982). Socio physiological factors associated with training needs of small and marginal farmers. Indian $J$. Ext. Educ., 18(3-4): 72-73.

Basu, D. (1993). Farmers decision making process in purchasing pesticides. Unpublished Ph.D. Thesis, Department of Agricultural Extension, Bidhan Chandra KrishiViswa-Vidyalaya, Mohanpur, West Bengal.

Chawang, J.K. and Jha, K.K. (2010). Training needs of Paddy Cultivators in Nagaland. Indian Res. J. Ext. Educ., 10(1): 74-77.

Darnal, R. and Bandiyopadhya, A.K. (2014). Assessment of Intervention needs for enhancing Ginger production in some selected areas of Darjeeling District, 
West Bengal. Intl. J. Dev. Res., 4(7): 1384-1385.

Pareek, U. and Trivedi, G. (1964). Manual of socio-economic status scale (rural). Delhi, Manasayan.

Roy, N.K. and Prasad, C. (1974). Training needs of farmers in relation to high yielding varieties of paddy. Indian Res. J. Ext. Educ., 10(3/4): 54-56.

Sagar, R.L. (1983). Study of agro economic, socio psychological and extension communication variables related with farmers productivity of major field crops in Haringhata block. Unpublished Ph.D. Thesis, Department of Agricultural Extension, Bidhan Chandra Krishi Viswa-Vidyalaya, Mohanpur, West-Bengal.

Singh, M.K. (2004). A study on technological gap in recommended packages of practices of rice production technology by the medium, small and medium farmers of Thoubal district, Manipur. Unpublished Ph.D. Thesis, Department of Agricultural Extension Bidhan Chandra Krishi Viswa-Vidyalaya, Mohanpur, West-Bengal.
Singh, Ng. (1993). The extend of adoption of improved rice practices by the schedule caste farmers of Manipur. Unpublished Ph.D. Thesis, Department of Social Science, Manipur University.

Srivastava et al., (2012). Assessment of the level of knowledge and training needs of potato growing tribal farmers of Meghalaya. Int. J. Agric. Environ. Biotecnol., 5(4): 483-487.

Verma, H.K., Patel, B.M., Patel, J.K. and Gulkari, K.D. (2013). Training needs assessment of marigold growers. Agric. Updat., 8(1/2): 257-259.

Virk, P.S., Khush, G.S. and Peng, S. (2004) Breeding to Enhance Yield Potential of Rice at IRRI: The Idotype Approach, IRRI, p. 5-9.

Zeng, J., Lu, X., Tang, X. and Tang, Y. (2004) The system of rice intensification (SRI) for super-high yields or rice in Sichuan Basin, $4^{\text {th }}$ International Crop Science Congress, Brisbane, Australia. In: hhtp://www.ciifad.cornell.edu/sri/countr ies.

\section{How to cite this article:}

Niranda Sharma Leihaothabam, Aheibam Tarajit Singh, Khumukcham Stina, Mutum Suraj Singh, Rajkumar Sandeep Singh, Yaikhom Vivekananda and Konsam Cha Shyamananda. 2020. A Study on Training Needs Assessment of Rice Growing Farmers in Imphal East District, Manipur. Int.J.Curr.Microbiol.App.Sci. 9(03): 66-74. doi: https://doi.org/10.20546/ijcmas.2020.903.008 